\title{
Long-Chain Fatty Acid Transport Protein 4
}

National Cancer Institute

\section{Source}

National Cancer Institute. Long-Chain Fatty Acid Transport Protein 4. NCI Thesaurus.

Code C106336.

Long-chain fatty acid transport protein 4 (643 aa, $72 \mathrm{kDa}$ ) is encoded by the human

SLC27A4 gene. This protein is involved in the mediation of both fatty acid transport and acyl-CoA conjug ation of long-chain and very-long-chain fatty acids. 